\title{
Ecological approaches to rural development projects
}

\author{
Enfoques ecológicos en proyectos \\ de desarrollo rural
}

Sandra Díaz 1

Daniel M. Cáceres 2

\footnotetext{
1 Instituto Multidisciplinario de Biología Vegetal y Facultad de Ciencias Exactas, Físicas y Naturales, Universidad Nacional de Córdoba, Casilla de Correo 495, Vélez Sársfield 299, 5000 Córdoba, Argentina. sdiaz@com.uncor.edu 2 Departamento de Desarrollo Rural, Facultad de Ciencias Agropecuarias, Universidad Nacional de Córdoba. Av. Valparaíso s/no, 5000, Casilla de Correo 509, Córdoba, Argentina. dcaceres@agro.uncor.edu
}

\begin{abstract}
Most rural development projects include ecological considerations, and most conservation projects include some reference to sustainable development. However, conservation projects frequently fail because they do not incorporate local communities' perceptions and needs. Many development projects are also unsuccessful because they are not based on adequate ecological assessment. We focus here on the most important ecological issues to be addressed in order to place development projects in an ecosystem context. Such projects should incorporate updated and precise ecological concepts and methods. Some key ecological issues in development projects are the relationships between ecosystem functions, services, and sustainability, the concept of loose connectivity, the distinct and complementary concepts of ecosystem resistance and resilience, and the links between biodiversity and ecosystem functioning. We claim that an ecologically sound development project maximizes the preservation and improvement of ecosystem services, especially for local communities. We pose a series of questions aimed at placing rural development projects in an ecosystem context and suggest ways of organizing this information.

Key words Rural Development; Sustainable Development; Ecosystem
\end{abstract}

Resumen La mayoría de los proyectos de desarrollo rural incluyen consideraciones ecológicas y la mayoría de los proyectos de conservación hacen alguna referencia al desarrollo sustentable. Una causa de fracaso frecuente de los proyectos de desarrollo es la falta de una evaluación ecológica adecuada. En este trabajo abordamos los aspectos ecológicos más importantes a considerar en proyectos de desarrollo rural. Resulta necesario incorporar métodos y conceptos ecológicos actualizados y precisos. Conceptos ecológicos útiles en la evaluación ecológica de proyectos de desarrollo rural son los vinculados a la relación entre funciones ecosistémicas, servicios ecosistémicos y sustentabilidad, la conectividad laxa, la resistencia y la resiliencia ecosistémicas, y los efectos de la diversidad sobre las funciones y los servicios ecosistémicos. Sugerimos una serie de preguntas que deberían ser contestadas a fin de situar los proyectos de desarrollo en un contexto ecológico y mencionamos algunos instrumentos para la organización y la sistematización de la información recogida.

Palabras clave Desarrollo Rural; Desarollo Sustentable; Ecosistema 


\section{Introduction}

In recent decades, the prevailing development model has entered a period of crisis (Rich, 1994; UNDP, 1995). One of the main critiques is the model's failure to combine economic growth with both equitable wealth distribution and environmental protection. Recent years have witnessed greatly increased awareness of the threats posed by human activities to the continuity of life on earth (Adam, 1994; Pretty, 1996). In response to this increasing awareness, it has become common to include ecological considerations in rural development projects.

On the other hand, most conservation projects are now expected to address social issues regarding peoples' interests and to approach development in a sustainable way. It is now virtually mandatory to include ecological assessment in rural development projects and issues of sustainable development in conservation projects. However, in many cases these explicit intentions are not reflected in the projects' everyday practice and final outcome. Conservation projects often fail because they do not appropriately incorporate local communities' perceptions and needs. For example, many ecologically sound afforestation initiatives fail in the medium to long term because local communities do not perceive trees as particularly important. Poor farmers usually have other priorities and cannot wait until the benefits of tree-planting programs become obvious. This is the typical case in which environmentally sound projects encounter socioeconomic obstacles, as illustrated by Pais (1997), who described a rural development project in Northern Argentina which planted tree species for timber, fuel, and fodder. The campesinos involved in the project showed no interest in planting trees, even though most of the costs were subsidized. The project failed to address the felt needs of local people, who failed to see the importance of planting these tree species. However, the situation changed when the development agents proposed to change the species and plant orchards. The new proposal was better suited to their interests, needs, and expectations, and the campesinos planted the trees.

Ecological issues also tend to be poorly incorporated into development projects, and some projects fail to incorporate them at all. In other cases there is an explicit interest in taking ecological aspects (e.g., impacts of development actions) into account. However, ecological assessment is usually based on superficial, sketchy, outdated, highly stereotyped, nonsituated ecological concepts. For example, a technology expert from an Argentine nongovernmental organization was concerned because the corn grinder used by a group of campesinos to feed their families was powered by fossil fuels. According to his view, this was environmentally damaging because the grinder produced greenhouse gases. At the other end of the spectrum, some development officers recommended using a wide range of agrochemicals on the assumption that they are harmless to the environment, providing farmers follow manufacturers' instructions (Cáceres, in press).

Given this lack of integration between social and ecological considerations, the current article focuses on two main questions: (1) What are the most important ecological issues to be addressed in order to place development projects in an ecosystem context? and (2) How can development projects be improved by incorporating an ecological dimension?

We begin by discussing the concept of sustainability. We then present some key ecological concepts which can be readily and productively incorporated into rural development projects, and propose a series of key questions that need to be answered in order to produce an ecological assessment of specific projects. Finally, we present a brief overview of sources and tools to gather and organize information, helping to maximize its usefulness to all stakeholders, and especially to local communities.

\section{Is sustainability "universal"?}

Criticism of the dominant development model has spawned a review of roles and strategies adopted by scientists and institutions working with development. As Kloppenburg (1991) suggests, institutions which have traditionally supported a conventional approach to agriculture, such as the United States National Research Center, are now moving towards the idea of sustainability.

The complex nature of interrelationships between nature and societies suggests that we are far from knowing which methods and systems in diverse locations will really lead to sustainability (Youngberg \& Harwood, 1989). According to Rigby \& Cáceres (1997), there is a growing consensus that sustainability has different meanings, implications, and consequences, depending on prevailing natural and socioeconomic environmental conditions. This means that sustainability should be viewed as a "situated" concept. This requires moving away from definitions that deal in abstract terms, concentrating instead on approaches focusing 
on specific geographical and historical situations. Therefore, it makes little sense to identify either "sustainable" or "unsustainable" agricultural practices or technologies. The sustainability of many technologies depends on the peculiarities of the ecological, socioeconomic, and historical context in which they are implemented.

Cáceres \& Rigby (1998) suggest that sustainability is a situated concept. This has two implications: (a) what is sustainable for a certain region, farming system, or type of productive activity may not be sustainable for another and (b) what is sustainable now for a certain productive system may not be sustainable tomorrow. The authors emphasize the temporal aspect of the concept, since it is only in retrospect that sustainable agriculture can be truly identified. This is an important point, since nobody can guarantee that a certain practice will remain "sustainable" forever. To argue this would imply that the situation in which agricultural production takes place remains stable and unchanged through time. Take the case of wind-powered electricity in the United Kingdom. A decade ago this alternative power generation source was widely endorsed as environmentally-friendly and harmless. However, Harper (1996) suggests that this consensus has now vanished, with different environmental groups asserting that wind farms generate too much noise pollution and destroy scenic landscapes. These arguments against wind-power generation were very difficult to predict a decade ago, and one may conclude that it is likely that we may now be overlooking crucial aspects of sustainability which will become apparent in later years. Therefore, not only do the criteria regarding the sustainability of particular agricultural practices change, but also the very concept of sustainability should be understood as historical, dynamic, and involved in a perpetual process of re-conceptualization.

\section{Some key ecological concepts}

Some ecological concepts, mostly developed in the last two decades, can be applied usefully to development projects. These include the relationships between ecosystem functions, ecosystems services, and sustainability, the concept of loose connectivity, the distinct and complementary concepts of ecosystem resistance and resilience, and the links between biodiversity and ecosystem functioning.

\section{Ecosystem functions and ecosystem services}

Ecosystem functions are processes that occur in ecosystems, such as production of biomass, transpiration, or decomposition of dead matter. Ecosystem services are the benefits that human populations derive, directly or indirectly, from ecosystem functions (Costanza et al. 1997; Daily et al., 1997). Food and fiber production are major examples of ecosystem services. Some less obvious examples include temperature regulation, water purification, soil protection, and recreation. The valuation of ecosystem services is not free from difficulties, uncertainties, or even moral arguments (for discussion see Costanza et al., 1997 and references therein). There is wide consensus, however, that the value of ecosystem services (including both its market and non-market components) can be extremely high, even if the most conservative approaches are taken. For example, on the basis of Costanza et al. (1997) and Stone et al. (1994), the ecosystem value of Latin American tropical forests, rangelands/grasslands, and non-coastal wetlands taken together can be estimated at US\$ 1.8 trillion, an amount higher than the region's combined Gross National Product. In the case of croplands, the estimated per hectare value of ecosystem services is very low as compared to the market value. In the case of natural and semi-natural ecosystems, the opposite is true: for example, the value of ecosystem services of tropical forests and wetlands can be one or two orders of magnitude higher than their respective market values.

Nevertheless, the value of ecosystem services is seldom taken into consideration in development projects. Also, the asymmetry in the benefits and costs of ecosystem services has hardly been acknowledged. This asymmetry stems from the fact not all services provided by an ecosystem are equally important for all stakeholders, and the costs of lost ecosystem services are not shared equally. For example, the ecosystem service value of non-coastal wetlands is very high because of their key role in water purification, water-level buffering, and biodiversity conservation. Some of these services are not directly beneficial to local communities, who in turn may have to cope with the costs of increased risk of infectious disease transmission. In the case of forests, the benefits of some ecosystem services, such as timber production, are harvested mostly by outsiders, whereas many of the costs of ecosystem service loss, such as soil erosion, decreased temperature buffering, and decreased availability of key 
medicinal species are "paid for" mostly by local inhabitants.

Based on the above arguments, it has become increasingly obvious that an adequate assessment of the values of ecosystem services and a search for equity in sharing the costs and benefits of those services should be an integral part of any development project. Furthermore, from an ecosystem perspective, an ecologically sound development project should maximize ecosystem services, especially for local communities. Sustainable development should thus include both the long-term preservation and improvement of ecosystem services and the fair distribution of their costs and benefits. In the following sections we discuss some key issues directly linked to the preservation and modification of ecosystem functions and services.

\section{Loose connectivity of ecosystems}

The first step in the assessment of ecosystem functions is often the analysis of major components (subsystems) and the flows connecting them. The concept of loose connectivity implies that not all subsystems within a system are equally connected to each other. Some subsystems are much more connected among themselves than to others, and not all the connections between subsystems are symmetrical (see examples in Chapin et al., 1996). These ideas, developed mostly within the framework of hierarchy theory (Allen \& Hoekstra, 1982; O’Neill et al., 1987), represent an alternative view to those still prevailing in some sectors of the conservation community. The concept of loose connectivity goes directly against the idea that everything is inextricably connected to everything else (O'Neill et al., 1987).

A corollary of this argument is that not all components are equally important for maintaining a system's integrity. For example, in semi-natural woodlands, the loss of some understory species may have some negative biological and cultural impacts, but the loss of the main tree species will certainly mean a drastic change in water and nutrient dynamics, accelerated soil erosion, and dramatic increase in temperature, in order words, the collapse of the whole system. These "key" species have been named "dominant species" (when they are both very abundant and very important, like the tree species in the example above), or "keystone species" (when their importance is disproportionately high in relation to their abundance, e.g., a population of disease-carrying mosquitoes in a wetland area; see Begon et al., 1986, for further elaboration on the two concepts).
This has important implications for ecologically-based development projects. It means that recognition of the magnitude and direction of connections among subsystems is indispensable, and that not all components merit the same attention. Considering that resources and time are nearly always limited, important components will inevitably receive too little attention if priorities are not clear.

\section{Ecosystem resilience}

Ecosystem stability implies a certain continuity in ecosystem structure and dynamics through time. Ecosystem stability and sustainability are strongly linked (Chapin et al., 1996). According to Leps et al. (1982), ecosystem stability has two components: resistance, or the ability to avoid displacement in the face of disturbance; and resilience, or the ability of a system to return to normal following a disturbance. Although both components are relevant to ecologically-based development projects, most of the following discussion will focus on resilience.

\section{Ecosystem functions and biodiversity}

Having stated the importance of the nature, magnitude, and continuity of ecosystem functions for human welfare, it is now appropriate to discuss their links with a concept which has also gained the headlines of academic and non-academic publications in recent years: the concept of biodiversity. Biodiversity can be defined as the number and composition of genotypes, species, functional types, and/or landscape units present in a given system. It is now widely accepted that both types and numbers of species are important to maintain a given ecosystem's functions, and that within a certain climatic envelope, different dominant species can drive a given system's dynamics in very different directions (Schulze \& Mooney, 1994; Chapin et al., 1997, 1998).

Changes in a species' abundance and identity, especially those influencing biomass production, water and nutrient dynamics, trophic interactions, or disturbance regime, can heavily affect ecosystem structure and dynamics (Chapin et al., 1997). For example, intercropping may be highly successful in a Prosopis (algarrobo or mezquite) woodland, since these trees do not cast dense shade, they have roots which capture large amounts of water and retain soil, they symbiotically fix nitrogen, and their nitrogen-rich leaves decompose quickly. Under the same precipitation and temperature 
regime, and growing on the same substrate, intercropping would be unfeasible if pines were to replace algarrobo as the dominant tree species.

The idea that species-rich ecosystems are "better" (i.e., more productive, more stable, more desirable in general) than species-poor ecosystems is now common knowledge in development circles (UNDP, 1995). There is some empirical evidence in support of this idea. Species, genotype, and landscape diversity maximize ecosystem resilience in the face of directional or stochastic variations in the environment or invasion by pests or undesirable exotic species (Chapin et al., 1998). Particularly in species-poor systems (such as agroecosystems), diversity may increase biomass production and the efficiency of resource use (see examples in Chapin et al., 1998). Diversity can thus be seen as an insurance policy against radical ecosystem change. Keeping high-diversity systems may not be the best option in order to obtain short-term profit, but may pay off in the medium to long term. For example, high genetic diversity of crops can reduce loss in the face of extreme climatic events (e.g., untimely frosts) and reduce the impacts of insect and microbial pests (see Matson et al., 1997, and references therein). Intermixing crop and natural vegetation patches within a landscape mosaic usually decreases pest damage, since natural vegetation provides habitat for natural enemies, thus promoting pest control in adjacent crop patches (Altieri, 1995).

There is often a positive relationship between biodiversity and ecosystem resilience. However, this is not a universal or thoroughly understood phenomenon. High species richness per se may not necessarily be desirable: highly disturbed areas tend to show high biodiversity, but this biodiversity is often related to the presence of a highly unstable assemblage of weedy species. The invasion of some seminatural rangeland ecosystems in Latin America and the Western Mediterranean by tall tussock grasses can initially increase their diversity, but through dramatic increase of flammability can decrease ecosystem resilience in the long term (Baruch, 1996; Lloret et al., 1998). Similarly, although high landscape diversity is usually good for the maintenance of key ecosystem services in agricultural plots and plantations, some counter-examples have been reported. For instance, in central Argentina, the existence of natural or planted wooded patches within agricultural areas, which appears as a sound practice from the point of view of biodiversity preservation, has been shown to increase the impact of the bird pests eared dove and monk parakeet on crops (Bucher, 1990; Navarro et al., 1992). In the Amazonian rainforest, deforestation in small patches increases the border effect on tree mortality, thus producing a sharp loss of above-ground tree biomass, which could be a significant source of greenhouse gases released upon decay (Laurance et al., 1997).

Although the conservation of the highest possible genotype, species, and landscape biodiversity seems to be the safest approach, these examples suggest that high biodiversity cannot automatically and dogmatically be equated with high ecosystem performance and resilience. It is therefore important to keep an open perspective and to avoid mechanical application of general principles to individual projects without careful evaluation.

\section{Ecological assessment within the context of specific development projects}

\section{Assessment of the system's structure and dynamics}

How can the ecological concepts outlined in the previous section be applied usefully to specific development projects? The above discussion may sound rather academic to those working directly in the field, and trying to make concrete - and often urgent - decisions. Rather than a complicated conceptual system, we propose a set of very concrete questions to be answered by both development agents and local community members. The list of questions in Table 1 merely illustrates the approach. Its length, content, and emphasis should be tailored to the needs of each specific development project.

\section{Sources of information}

Both scientific and indigenous knowledge are needed to appropriately address these questions. A thorough review of published papers and reports related to the main issues arising from the above questions is important in order to obtain a general background. Basic textbook type ecological information is often very general and does not consider "real" farming systems, although it can provide some useful concepts to develop a general framework (such as those discussed above). Case studies or applied ecological work may provide more suitable information. Although this may seem obvious, it is not. Development officers frequently fail to thoroughly search the sources that 
Some key questions to be answered in order to evaluate the ecological dimensions of rural development projects. Local-scale projects have been emphasized.

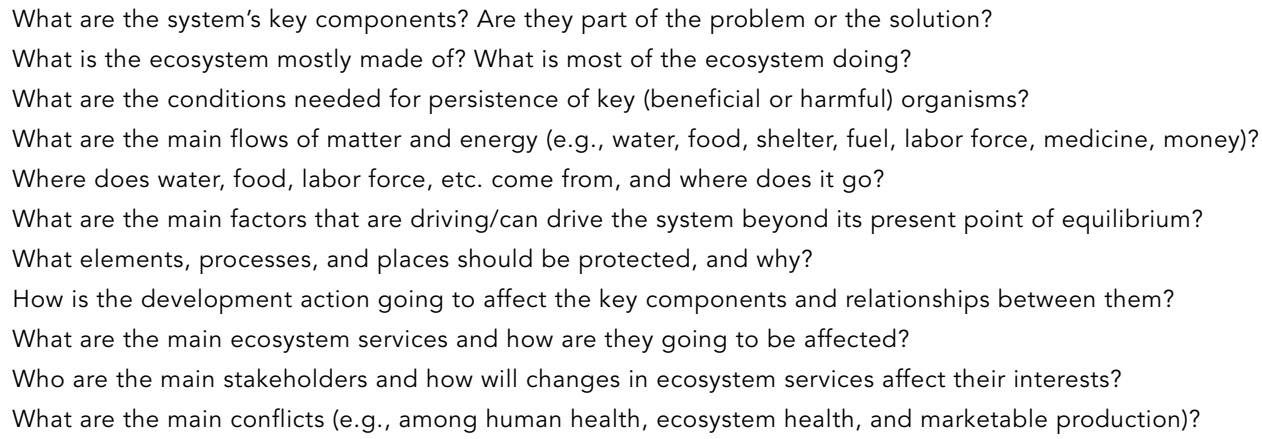

could provide valuable knowledge. In addition, consideration of local communities' perspectives and knowledge is vital to understand key issues related to the evaluation of ecological dimensions in development projects. However, we should highlight that local knowledge is not infallible, since it has been eroded by acculturation processes generated by market penetration, mass media, and modernization in general. In many rural communities, a considerable portion of traditional ethnoecological knowledge (e.g., medicinal plants for people and animals, wildlife management) has already been lost, as young people tend not to be interested in absorbing knowledge from their elders. This is not to say that indigenous knowledge is superfluous or intrinsically less reliable than scientific knowledge. On the contrary, it must be taken into account if a deep understanding of some ecological processes is expected. A critical analysis by development agents helps identify its potential and limitations in specific cases.

In short, and following Cáceres \& Rigby (1998), indigenous knowledge and modern science should not be counterpoised, because they do not represent mutually exclusive sources of information. They should not be viewed as competing approaches, but as different and potentially complementary ways of approaching the evaluation of rural development projects.

\section{Some tools for systematizing information}

Once the information is gathered, or even during the information-gathering process, the approach to summarizing and systematizing information is not a trivial issue. Bulks of information which cannot be easily visualized do not help local communities to really internalize the information or to discover previously unseen connections among components, possible conflicts, or likely thresholds. Some promising tools are flow diagrams, maps, and grids of ecosystem services by stakeholders.

When using diagrams, main components and the flows between them are indicated. It is particularly important to describe the direction and magnitude of fluxes between components, since this is a powerful way of visualizing relationships and potential impacts which are not obvious at first inspection.

Maps also provide a very useful basis for discussion and interaction. Simple, not necessarily high-tech, geographic information systems can be built, in which each point in space has many layers, corresponding to their basic physical features, social meaning, ecosystem service value, vulnerabilities, etc. (see Harmsworth, 1998, for a more comprehensive example).

Finally, grids of ecosystem services by stakeholders can be jointly constructed by development agents and local communities. In such grids, each ecosystem service and the benefits and costs involved in each development action are analyzed from different stakeholders' perspectives. This provides a good starting point for negotiation and conflict resolution.

\section{Final remarks}

In order to increase their chances of success, development projects need to be framed within good knowledge of ecosystem dynamics, as well as within knowledge of strategies for social reproduction by local communities. There is no 
general recipe for conducting ecosystem assessment that is suitable for all rural development projects, because sustainability is a situated concept, and there is no development action that is sustainable in all systems at all times. Still, some guidelines can be proposed, including the need to incorporate updated and precise ecological concepts and methods. This paper has outlined some of these concepts and methods. At this point we should stress that the most crucial aspect in the ecological assess-

\section{Acknowledgments}

We thank the organizers of the International Meeting "An Ecosystem Approach to Human Health: Communicable and Emerging Diseases (IDRC-Canada and UNEP). We are also very grateful to David WaltnerToews for encouraging us to write this article. ment of a development project is not the kind of tools employed. The key is rather what questions are asked, and especially how they are answered. Sharp questions tailored to the specific situation at hand, and precise answers by all stakeholders, based on an honest view of the situation (sometimes expressed as "keeping open eyes and an open mind") are probably the closest we can come to a recipe for an ecosystem assessment of rural development projects.

\section{References}

ADAM, B., 1994. Running out of time: Global crisis and human engagement. In: Social Theory and the Global Environment (M. Redclift \& T. Benton, eds.), pp. 92-112, London: Routledge.

ALLEN, T. F. H. \& STARR, T. B., 1982. Hierarchy: Perspectives for Ecological Complexity. Chicago: University of Chicago Press.

ALTIERI, M., 1995. Agroecology: The Science of Sustainable Agriculture. London: Intermediate Technology Publications.

BARUCH, Z., 1996. Ecophysiological aspects of the invasion by African grasses and their impact on biodiversity and function of Neotropical savannas. In: Biodiversity and Savanna Ecosystem Processes (O. T. Solbrig, E. Medina \& J. F. Silva, eds.), pp. 79-93, Berlin: Springer-Verlag.

BEGON, M.; HARPER, J. L. \& TOWNSEND, C. R., 1986. Ecology: Individuals, Populations and Communities. Sunderland: Sinauer.

BUCHER, E. H., 1990. The influence of changes in regional land-use patterns on Zenaida dove populations. In: Granivorous Birds in Agricultural Landscape (J. Pinowsky \& J. D. Summers-Smith, eds.), pp. 291-303, Warsaw: Polish Academy of Sciences.

CACERES, D. \& RIGBY, D., 1998. Sustainability: Does it Imply the Same to North or South? Manchester: Universidad Nacional de Córdoba, and University of Manchester. (mimeo.)

CACERES, D. (in press). Tecnología para Pequeños Productores Agropecuarios. Buenos Aires: Proinder.

CHAPIN III, F. S.; SALA, O. E.; BURKE, I. C.; GRIME, J. P.; HOOPER, D. U.; LAUENROTH, W. K.; LOMBARD, A.; MOONEY, H. A.; MOSIER, A. R.; NAEEM, S.; PACALA, S. W.; ROY, J.; STEFFEN, W. L. \& TILMAN, D., 1998. Ecosystem consequences of changing biodiversity. Bioscience, 48:45-51.

CHAPIN III, F. S.; TORN, M. S. \& TATENO, M., 1996. Principles of ecosystem sustainability. American Naturalist, 148:1016-1037. 
CHAPIN III, F. S.; WALKER, B. H.; HOBBS, R. J.; HOOPER, D. U.; LAWTON, J. H.; SALA, O. E. \& TILMAN, D., 1997. Biotic control over the functioning of ecosystems. Science, 277:500-504.

COSTANZA, R.; D'ARGE, R.; DE GROOT, R.; FARBER, S.; GRASSO, M.; HANNON, B.; LIMBURG, K.; NAEEM, S.; O'NEILL, R. V.; PARUELO, J.; RANSKIN, R. G.; SUTTON, P. \& VAN DEN BELT, M., 1997. The value of the world's ecosystem services and natural capital. Nature, 387:253-260.

DAILY, G. C., 1997. Nature's Services: Societal Dependence of Natural Ecosystems. Washington, D.C.: Island Press.

HARMSWORTH, G., 1998. Indigenous values and GIS A method and a framework. Indigenous Knowledge, 6:3-7.

HARPER, P., 1996. Energy in England. Resurgence, 174: 26-27.

KLOPPENBURG Jr., J., 1991. Social theory and the de/reconstruction of agricultural science: Local knowledge for an alternative agriculture. Rural Sociology, 56:519-548.

LAURANCE, W. F.; LAURANCE, S. G.; FERREIRA, L. V.; RANKIN-DE-MERONA, J. M.; GASCON, C. \& LOVEJOY, T., 1997. Biomass collapse in Amazonian forest fragments. Science, 278:1117-1118.

LEPS, J.; OSBORNOVA-KOSINOVA, M. \& REJMANEK, M., 1982. Community stability, complexity and species life history strategies. Vegetatio, 50:53-63.

LLORET, F.; VILA, M. \& O'GHERI, E., 1998. Fire-grass positive feedbacks in Mediterranean shrublands: The Ampelodesmos mauritanica study case. Abstracts of the Earth's Changing Land GCTE-LUCC Open Science Conference on Global Change (Global Change and Terrestrial Ecosystems, International Geosphere and Biosphere Programme - GCTEIGBP, ed.), pp. 102-103, Barcelona: GCTE-IGBP.
MATSON, P. A.; PARTON, W. J.; POWER, A. G. \& SWIFT, M. J., 1997. Agricultural intensification and ecosystem properties. Science, 277:504-509.

NAVARRO, J. L.; MARTELLA, M. B. \& BUCHER, E. H., 1992. Breeding season and productivity of Monk Parakeets in Córdoba, Argentina. Wilson Bulletin, 104:413-424.

O'NEILL, R. V.; DE ANGELIS, J. B.; WAIDE, J. B. \& ALLEN, T. F. H., 1987. A hierarchical concept of ecosystems. Monographs in Population Biology, 23:1-272.

PAIS, A., 1997. Cachi: Con los árboles ¡ni regalados! In: Detrás del Árbol la Gente (Deutsche Gesellschaft fur Technische Zusammenarbeit - GTZ, ed.), pp. 24-26, Salta: Proyecto de Desarrollo Forestal en Comunidades del Noroeste Argentino/ GTZ.

PRETTY, J. N., 1995. Regenerating Agriculture. London: Earthscan.

RICH, B., 1994. Mortgaging the Earth. The World Bank Environment Impoverishment and the Crisis of Development. London: Earthscan.

RIGBY, D. \& CACERES, D., 1997. The sustainability of agricultural systems. Institute for Development Policy and Management Working Papers, 10:1-38.

STONE, T. A.; SCHLESINGER, P.; HOUGHTON, R. A. \& WOODWELL, G. M., 1994. A Map of Vegetation of South America Based on Satellite Imagery. Woods Hole: Woods Hole Research Center/American Society for Photogrametric Remote Sensing.

UNDP (United Nations Development Programme), 1995. Agroecology: Creating the Synergism for a Sustainable Agriculture. New York: UNDP.

YOUNGBERG, G. \& HARWOOD, R., 1989. Sustainable farming systems: Needs and opportunities. American Journal of Alternative Agriculture, 4:100. 